\title{
Transfers between Spaces of Communication, Tourism and Staging of Heritage
}

\author{
Christian Dennys Monteiro de Oliveira \\ Department of Geography, University Federal of Ceará, Fortaleza, Brazil \\ Email:cdennys@gmail.com
}

Received 12 January 2016; accepted 14 March 2016; published 17 March 2016

Copyright (C) 2016 by authors and Scientific Research Publishing Inc.

This work is licensed under the Creative Commons Attribution International License (CC BY). http://creativecommons.org/licenses/by/4.0/

C) (i) Open Access

\begin{abstract}
The present study represented an interpretation resulting from a survey on the property representations of religious festival held in Almonte (Huelva, Spain), during the transfer of the image of the Virgin of Rocio seat of the municipality, between August 2012 and May 2013. The investigation collected opinions of teachers and students from two secondary schools in the city, in order to characterize the educational meanings of such an extraordinary event and organizer of cultural expressions. Reading the geographical links between heritage and forms of dissemination (media and tourism), led us to develop the concept of "geo-education". Structured from the phenomenological and cultural perspectives that underpin geographic readings in culture studies, the geoeducation emerges as a non-formal teaching of the meaning of the festive reordered places rituality (or religious representations). Sense that answers to the recognition of the vectorial forces (communicative, tourist and scenography) are intermediated by the contemporary patrimonial question. The result of the work lies in the composition of basic theoretical syntheses of treatment and use of modern religious devotion as geo-education's heritage.
\end{abstract}

\section{Keywords}

Transfers, Representation, Geo-Education, Heritage, Symbolic Vectors

\section{Introduction}

In 2012, the Catholic Sanctuary of “El Rocio” village, located in Almonte County (Huelva, Spain) lived an exciting Marian devotional re-appropriation episode. In the morning of August 20, just five days from the jubilee year decreed by Pope Benedict XVI, the Virgin of Rocio was the most imposing pilgrimage in history, celebrat- 
ing the $200^{\text {th }}$ anniversary of the bicentennial festivity known as "Rocío Chico". This jubilee represented to the host city more than just an act, among many of them, but the confirmation of the incomparable symbolic and administrative burdens that the Brotherhood Matrix of Almonte plays in patrimonialization of this devotional culture. This fact allows us to investigate how much the other Brotherhoods-all the others 112 associations with legitimate canonical rights to worship the Virgin of Rocio-beyond the Episcopal Catholic Church and the government-cooperate to this confirmation. No doubt, that is an interesting reflection object to the continuation of our studies.

The focus of the analysis that begins with the geographical and educational representation of this event, directs its view to the school's expressions on the cultural accommodation of that symbolic moment. The Saint's visit occurs every seven years. The earlier visit occurred in 2005, distancing the annual memory of the younger ones and not bringing the more mature ones the mythical density and logistics that the Bicentennial Jubilee has aroused. The Municipality and the Brotherhood of Almonte, through the canonical granting from Pope Benedict XVI, had the Marian Jubilee Year of the record (in the City, County and Rocio Village).

The most important concept in this presentation is to show the event as a cultural expression, relevant and institutionalized, both for the Church and for the Spanish State. The one that allows treating the festivity in the ecclesial, civil and cultural articulation as investment fully justified for the overcoming of the socioeconomic and environmental problems that reach Spain since the beginning of the financial crisis of 2008. The turn of this biennium could represent to Almonte a significant tourism and heritage gain, and in the condition of host-village assumed the central place of peregrination in honor of the Virgin of Rocio, in nine months period (August 19, 2012 to May 12, 2013).

The Chico's Rocio in 2012, occurred in the second decade of August, and it had condensed to an atmosphere of strong emotional and heritage appeal, that had opened the Marian Jubilee Year. The processional change coincided in its seven years cycle starting from 1949 with the Bicentennial of the Almonte Brotherhood Matrix peregrination to the Holy village. It has allowed the direct question about its symbolic and vectorial representation through the educational heritage expressed over this event. In what extent local youth, students of primary schools in Spain, corresponding to Secondary School and Bacchirelatto understand the strength of this heritage representation? Consequently, how do the involved teachers position themselves in the formation of this cultural content? Has the school be cooperating with it or rearranging a religious process that completely modifies the routine of the Almonte village?

Such questions had a preliminary version in this heritage formation study, in the context of the Pentecost Peregrination (Rocío Grande) in 2011. Its first identified elements were published as paper, book and article directly linked in the final work (Oliveira, 2012). However, it has required a specific treatment in the dialogue with regular school, starting from these reflections, which has become timely in January 2013, when we conduct the empirical part of the research. The items, in this first part, explore therefore the central context of the opportunity fomented in the peregrination of 2012/2013. Continuing the discussion, we translated it by tabulating the questionnaires and moves forward in the reflection on the phenomenological and vector nature of Geo-education. Equivalent festivities consolidate it, until rediscover a more epistemological proposition in relational Geography in the political-religious imaginary field. The conclusion will allow us to say, with the metaphor of the return of the Virgin to the traditional Sanctuary of Rocio, if the events of Pilgrimage and Jubilee were just extraordinary expedients or if there is, potentially, a spatial continuity of the Religious festival, integrated in the Heritage Education-HE (IPCE; OEPE, 2012). Especially the one that involves the Geography Teaching, which still refuses to absorb these themes.

\subsection{The Religiosity and the Event}

The religiosity forms and processional acts in the countryside of Andalusia harmonize with all political-cultural relationship of mythical renewal of the Christian reconquers in the Iberian Peninsula. The Andalusian territory represents the last spot of Moorish resistance, in the medieval process that extended from the XI to the XV century, more precisely in the year of 1492, the simultaneously marks of Granada (eastern Andalusia) conquest and the arrival of the Columbian caravels in American lands.

In the end of the XVI century, Seville, the Andalusian capital, polarized the colonial richness and represented the southern Spain and the splendor of the agrarian representation of the Iberian Mercantilism. Although Spain has competed with Portugal the sovereignty of Atlantic routes, Andalusian was facing stagnation. The anthropologist Rodriguez Becerra, who has studied the Andalusian religiosity, presents a cultural schema of this 
process:

La religiosidad andaluza la caracterizan algunos por su anacronismo y dependencia que tiene su origen en el retraso económico y en el tardío acceso generalizado de los jóvenes a la enseñanza secundaria y universitaria... y se expresa por sus manifestaciones barrocas, probablemente por corresponder este período con la última etapa de esplendor de la región y de sus ciudades. La estética barroca, reelaborada por la concepción romántica que exalta la sensualidad, se ha convertido en un canon riguroso del que salirse es casi imposible (Rodriguez Becerra, 2006: p. 25).

Therefore, a limited economic development and delayed access to medium schooling in Brazil equivalent to $8^{\circ}$ e $9^{\circ}$ grades from basic education, add to three years of high school-could help to justify the adherence to a Baroque religiosity. The memory of Splendor, placed in a mythic place of Spanish empire, would help to fix the romanticism of rites and the sensuality captured in a cosmopolitan relationship with others cultures (Gypsises, Moors, and Latin Americans). But the author opinion is guided in the comparison between Andalusian religiosity and formalities of catholic rites, which are less exultant and present in others Spanish regions. Would it have others modern-day factors?

The images found in everyday experience of Huelva (Andalusian province that polarized the Bicentennial), while the permanence of Virgin in Almonte induce us to a more synchronous hypothesis about the links between religion and the event (see Figure 1). This is not only about a Baroque and agrarian tradition that can't unlink each other. The Andalusian regional reality represents a harmony model with the contemporary process of construction, democratic and confederation, of the Spanish Autonomic Communities state (Henares Cuéllar, 2010). In this context, the articulation of the Andalusian heritage-including the festivities and their scenarios-develop as a link to the cultural production of the historical heritage assets (Escalera Reyes, 2009).

According to Castillo Ruiz, the territory bond involves the Spanish Historical Heritage Law (L.E.P.H. 16/ 1985), "el patrimonio cultural se observa desde la diversidad regional o de los pueblos de España mientras que lo que afecta al común se entiende como legalidad preestablecida e indiscutida” (Henares Cuéllar, 2010, 59). This argument evokes a legal incentive to a political construction of unique events that celebrates the anatomic increment of the Spanish culture in Andalusian geographic regional forms. In this sense, the religiosity doesn't fit, solely because the resistance of the historical traditions in the region, but also, because the heritage design of certain religious festivals, in local scenarios properly updated, which promotes a frank dialogue with the current geographical conditions (Vicente Carmona, 2010). Tourism incentive, economic recovery of a financial crisis, response to social demands for technologically qualified public services and political space for discussion of regional organizations. When Almonte received the commemorative parade of 200 years from the biggest rocieira brotherhood-the Triana Brotherhood, hosted in Seville (capital)-it reconfigures itself as a space of active symbolic power. Not only religious but also illustrative. That is one differential value to debate.

\subsection{City and Education}

Huelva, the most occidental Andalusian province, makes territorial border with Portuguese Algarve (east), with
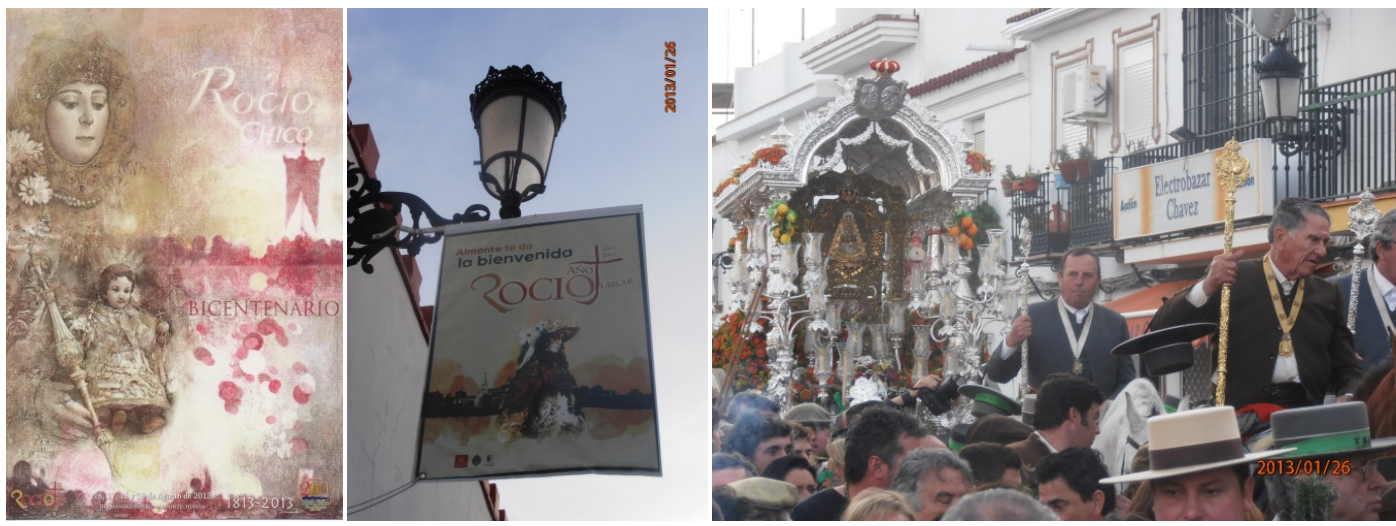

Figure 1. Bicentennial poster and Jubilee Year in Almonte welcoming the Brotherhood of Triana. Source: Author's personal files Images. 
Badajoz, Extremadura (north) and Andalusian provinces Seville and Cádiz (west), where it also located the municipality of Almonte (http://www.diphuelva.es/). Huelva has four geo-environmental boundaries, known as "ComarcasNaturales": Sierra (north, Serra Morena domains), Andévalo (historical site of mining exploration), Condado-Campina (characterized by wine production) and Costa (centered in the port capital Huelva). Coinciding with the areas on the east coast, the park complex of Doñana Park (an autonomic, national and global patrimony) occupies much of the Almonte territory. It not only defines the coastal fringe, but also consolidates the rural area, plain terrains, sandy, wetlands, where there is an agricultural and extractive activity, essential to the rocieiro festive context.

The Huelva Tourism Guide (2009/2010 edition)—Huelva de La Luz—as well as the official website of "Ayuntamiento" (Municipality) reaffirms the Almonte conditions as a coastal municipality, directly linked with the devotional religiosity to the Virgin of Rocio. In this sense, the two big annual pilgrimage in May/June (Rocio Grande) and August (Rocio Chico), articulated to the rural and equestrian traditions around Doñana Park, bringing to Almonte a cultural polarity peculiar to Huelva tourism development (Muñoz Bort, 2007). For this reason the extraordinary celebration of pilgrimage, each seven years, represents inflows of big political-economic investments. This makes some documents, as the study produced by Julio Flores Cala (2005), Historia $y$ documentos de lostraslados de la Virgen del Rocío a la Villa de Almonte 1607-2005, an indispensable scientific and technical contribution to the urban development management. The growing concern about the three urbanization spots (Downtown, El Rocio village, and the Matalascañas Atlantic Balneary).

The increasing concern about the three urban sites (Downtown, the El Rocio village, and the Matalascañas Atlantic Balneary) provides different challenges to the territory planning front the ecosystem sustainability. Especially to the main downtown spot, an article named El Ayuntamiento de Almontepresentamás de 50 proyectos al segundo Plan de Desarrollo Sostenible de Doñana from the online newspaper Huvelva 24. com shows in the 22 February edition the following quote:

Volviendo a Almonte, se han solicitado otras iniciativas de carácter urbanístico. Sobresalen la reurbanización y adecuación de la Plaza Virgen del Rocío, para adaptarla a las Venidas de la Virgen (500.000 euros), así como elproyecto turístico denominado 'Recorrido de la Pastora' (70.000 euros); la mejora de la movilidad urbana en diferenteszonas: Carretera del Rocío (450.000 euros), Chaparral (500.000 euros) y Ciecema (400.000 euros). Finalmente, lamejora de la permeabilidad y accesibilidad al casco urbano en Almonte (200.000 euros).

The investments projections represent the consensus about the agriculture, cultural and tourism interdependence, centering the economic development in the municipality. For this reason, the permanence of the Virgin of Rocio during the nine months, consecutive, represents an influx of visitor in the event, facilitating the business visibility in time of economic crisis and alarming unemployment. Especially the young population (from 16 to 25 years old) which the unemployment reach 56\% in March 2014 (data available in the website http://politica.elpais.com/politica/2014/03/20/actualidad/1395353300_217575.html) this represents almost twice the number in the Autonomous Community of Andalusia: 34.9\% — the biggest in Spain.

It is, in this juncture, that the event as special as the pilgrimage of the Virgin of Rocio, in a year marked by Canonical Jubilee in honor of the Bicentennial Rocio Chico, stays in the scope of political investment and economic compensation. This also reflects in the pedagogic approach of schools involved in this study-the Secondary Education Institute (IES) "Donaña” and "La Ribera” (see Figure 2). Schools published their basic documentation and classroom activities for the research we organized here. Both of the institutes are neighbors to the north exit of the city, via the La Juventud Avenue and the Che Guevara Street, that access the Highway A-483 (the main connection to cities like Huelva and Seville). In the south direction, going through downtown, or through the highway, it reaches the Rocío Village (in $15 \mathrm{~km}$ ) and the Matalascañas Village Beach (in $30 \mathrm{~km}$ ). That is why the schools involve both a local treatment as regional access to students from other urban and rural surroundings.

The IES "Doñana" (http://www.juntadeandalucia.es/averroes/centros-tic/21700654/helvia/sitio/\#) became itself a regional reference, because, besides the secondary regular education, it also involves a preparatory course to access the higher education (Bachillerato) and special classes in bilingual education (Castilian and English). This is a very well established school structure, with facilities relatively well preserved and diverse, to service of about 1100 students. The IES "La Ribera” (http://todoeduca.com/centros/huelva/almonte/laribera60780.html), younger and smaller, serves an audience of almost 450 students, and it is directly aimed to the high school, taking students from two local primary schools, with a structural and more limited socioeconomic profile. 


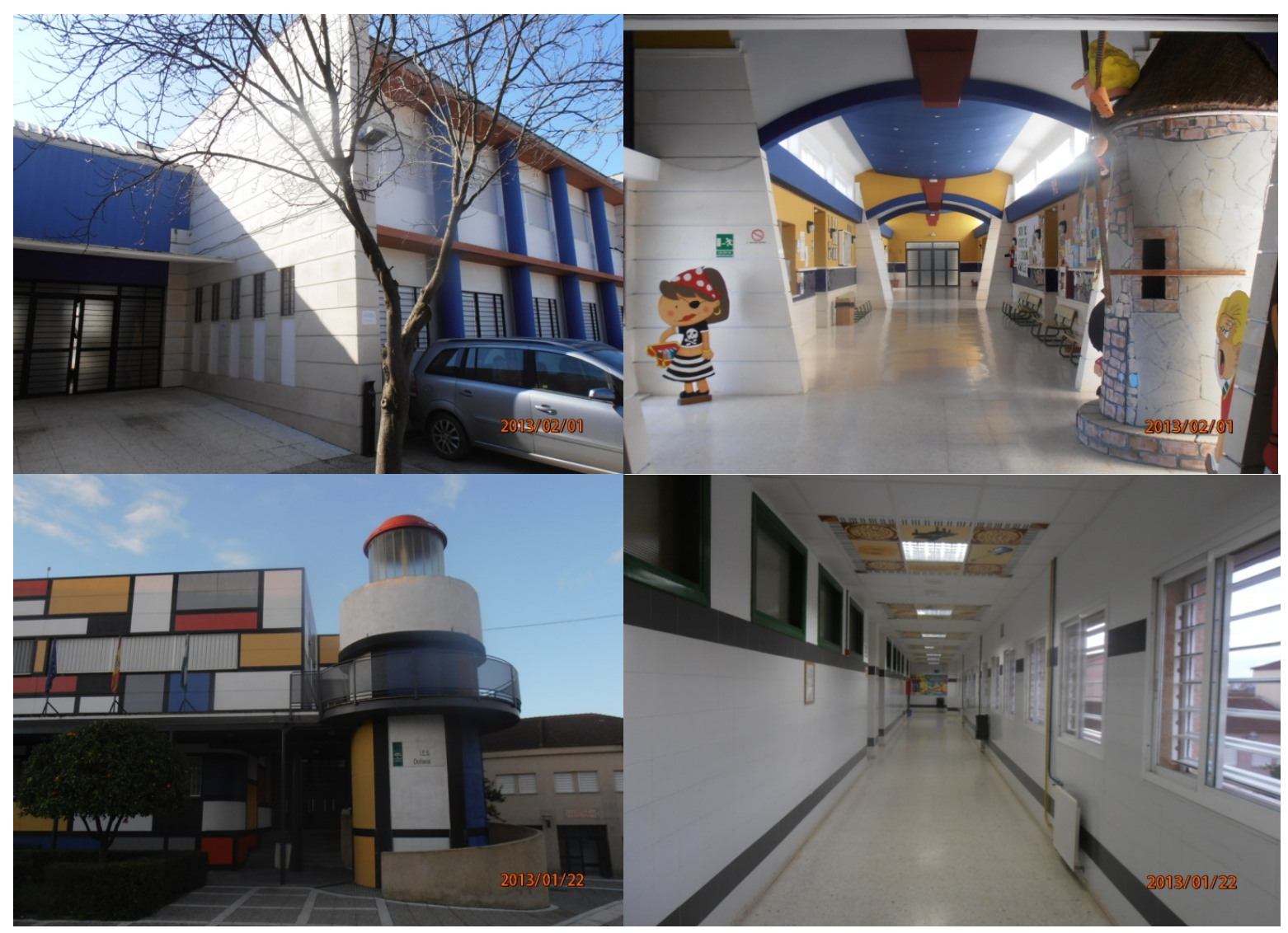

Figure 2. Images from the visited and researched Institutes: La Ribera (above); Doñana (below). Source: Author's personal files Images (2013).

Both of them, however, are marked by two social background of strong cultural relevance when we investigate the school actors (students and teachers) with an appreciation of the city when it is in the festivities. It was registered a high number of foreigners and descendants of immigrants (African, Latin American, Eastern European), demonstrating the concern about the structure of technical projects of social inclusion. On the other hand, there are also the perception of interdependence between the school calendar and multiple events of the Rocío festivity.

\subsection{Methodological Paths}

The empirical access to the geographical reality of the province of Huelva and the town of Almonte was between 08/01 and 07/02 of 2013, developing the field work of the study "Turismo e PatrimônioGeoeducacional" (funded by the Foundation Carolina de Madrid-Espanha). The direct contact with the Education Faculty of the Huelva University (UHU) was fundamental to search scientific ground to interim visions of the Heritage Education, Religious Tourism and the theory of social representations (Sá, 1996). The objective was to support the collecting of written information, from teachers and students, from the Secondary Education Institute (IES), in the city of Almonte (Huelva).

Therefore, the field study during 30 days, on one side, linked a permanent attendance work and daily life in the offices and library of the Campus El Carmen, in the UHU; on the other side, a total of 5 field trips (with 2 night stay) to make contacts, meetings and applying the questionnaires in Almonte (the city is $60 \mathrm{~km}$ from the province's headquarter). This alternating process allowed us to understand the latent difficulties to absorb information from the event, which had not an interpretation focus in its cultural or business occurrence, but its representation in the educational field.

This educational field pointed out as "challenging" by researchers themselves with whom we work in partnership: the teachers Jesus Estepa Gimenez e José María Cuenca López. Their researches focus, respectively, on 
the high school's curriculum representation and in the planning of cultural heritage material in archives and museums (Cuenca López, 2002; Martín Cáceres, 2012). This made the focus in the intangible heritage (festivities and popular religiosity) distinguished contributions to the reflections on school links with such cultural property. The realization of this methodological approach involved four phases, 3 empirical and 1 additional:

- Phase 1: Preliminary contacts in Almonte for final formatting of the categories of analysis and composition of questionnaires to students.

- Phase 2: Delineation of strategies in schools (La Ribeira and Doñana), with application of questionnaires and delimitation of groups of teacher consultation.

- Phase 3: Reworking the central issues in view of the categories and apply them with the teachers; and monitoring the dynamics of the festive activities in the city, in our field visits.

- Phase 4 (additional): Get interviews of students involved in the closure of the pilgrimage festivities and registering News printed from the main journalistic vehicles. For that, 149 questionnaires were answered by students of two schools. In this selection the used criterion was the teachers' direct performance interviewed in the groups of $3^{\text {rd }}, 4^{\text {th }}$ and $5^{\text {th }}$ year.

When consolidated these phases, we tried to return to the team of teachers selected, scheduling a meeting to finish the empirical study. On this occasion, we pass to teachers Jesus Estepa and José Cuenca (tutors) a list of items that summarize the documents collected in this period. The same list that, back to Brazil, we used to support the analysis of this field period (see Table 1). The demands for the period May/2013 was also recorded when happened the last celebrations of the Pilgrimage of the Virgin Image, in Almonte, involving some kind of exchange with the schools. That way, we indicated the ending of all the phases from the research. Then, we receive from the teachers Victor Bocanegra (Chief of Geography and History Department from IES Doñana) and María Jesús Gómez Soldado (Director of IES La Ribera) 6 representative forms, answered by students who participated directly in the final Pilgrimage of the Virgin to Aldeia. Following the items comprising the documentation gathered in four phases.

\section{The School Representation about the Pilgrimage}

Considering the phases that are in the table above, we develop the details about the results, in view of the three privileged sources that we considered in the empirical consultation about the Pilgrimage of the Virgin to El Rocio and Almonte, in the Bicentennial Rocio Chico (2012/2013).

\subsection{The Teacher's View}

The teacher's view about the Heritage Educational representations, especially centered in the experience in the Pilgrimage of the Virgin, demonstrated us limits of dimensions about heritage issues in the Basic Education. On one hand, there is an effective and constructive commitment to encourage a contextualized learning of scientific

Table 1. Activity and products from the search.

\begin{tabular}{lll}
\hline Phases & Executed Activities & Collected Documents \\
\hline 01 & $\begin{array}{l}\text { Meeting work for preparation of students } \\
\text { questionnaires }\end{array}$ & $\begin{array}{l}\text { Introduction letter and authorization for access to the two secondary } \\
\text { schools-Deadline to the application of the questionnaires. }\end{array}$ \\
01 & $\begin{array}{l}\text { Access to the central Library of the Campus El } \\
\text { Carmen and the online consultation system. }\end{array}$ & $\begin{array}{l}\text { Lending two lots of books in benefit to theoretical studies ( related to } \\
\text { the study theme) }\end{array}$ \\
02 & $\begin{array}{l}\text { Technical visits to the City of Almonte and the } \\
\text { two IES that participated in the research }\end{array}$ & $\begin{array}{l}\text { Getting } 149 \text { questionnaires, from } 3^{\text {rd }} \text { and } 4^{\text {th }} \text { years of Secondary school } \\
\text { and Bachelor Degree. Institutional interviews. }\end{array}$ \\
02 & $\begin{array}{l}\text { Monitoring the festivities; visit to Triana } \\
\text { Brotherhood in Almonte. }\end{array}$ & $\begin{array}{l}\text { Photographs and news from press; highlight the integration between } \\
\text { religious tourism and the calendar of urban events. }\end{array}$ \\
& $\begin{array}{l}\text { Summarizing the questionnaires and interview } \\
\text { with the teachers }\end{array}$ & $\begin{array}{l}\text { Application and getting the } 5 \text { questionnaires from the teachers in } \\
\text { meetings in the IES-Schedule the activities in May/2013 }\end{array}$ \\
& $\begin{array}{l}\text { International Fair of Tourism in Madrid; visit in } \\
\text { the city boards. }\end{array}$ & $\begin{array}{l}\text { Folders that highlight the itineraries, European and Spanish, of } \\
\text { religious tourism. Photographic records. }\end{array}$ \\
& $\begin{array}{l}\text { Monitoring News until the return of the } \\
\text { Pilgrimage to Village }\end{array}$ & $\begin{array}{l}\text { News from the online journal www.huelvainformación.es, more } 6 \\
\text { questionnaires from students who participated the final Pilgrimage. }\end{array}$
\end{tabular}

Source: Author's elaboration (2014). 
and modern content; on the other hand, persists a structural distrust about cultural concession, if it can or should be given to the reproduction of traditions, costumes and festive practices, as they are tied to the religious sphere; in this sense, therefore, so detached from the scientific knowledge parameters.

The five teachers we interviewed showed very little objection to work the content in their disciplines (history and geography) and recognizing the cultural expression of the Andalusian festivities in the school community of Almonte. However, in spite of that, they affirmed a willingness to focus their works, eventual or permanent, on any reference to this heritage phenomenon.

Let's see how the teachers answered the issues raised by us:

Considering the five interviews, we selected one that best represented the predominant link between the educators and the Institutes. In none of them the Pilgrimage and it presence of the Holy in the city deserved justification for a differentiated schedule in the Department of Humanities.

In general, what manifested in teacher discourse, written or spoken, is the recognition of a contradiction, which has no overcoming conditions. On one hand, the Pilgrimage, is not pedagogic and existentially part of teacher's values, on the other hand, there isn't justification enough to incorporate this specific issue on the agenda of educational work. As stated by the teacher selected here to represent the thought of her colleagues in the two institutes: "I'm not with it (the event) and I believe the students give too much importance to it". Therefore, the emphasis of the students on the importance of the everyday celebrations and its consequent heritage appreciation-it is not incorporated as a "positive" educational problem; that is, it doesn't drive the thematic and conceptual construction of schoolwork. Then, in the end of the interview, the teachers indicate care about the Heritage Education: this radicalized forms of thinking fit exclusively for this events (festival, pilgrimage).

It was timey receive from the same teacher, months after the interview (in May 2013) a set of four questionnaires filled by four students who pointed their weak engagement in the completion of the pilgrimage: the return of the Virgin of Rocio to the holy village. In all, six questionnaires returned from the two institutes, following the request from the researcher who couldn't keep up with the decisive closing moments of the festivities. One of it, from a foreign student (Romanian birth) indicated in his justification of participation a dimension relatively ignored of the recovery process of contemporary popular festivals; and its frank patrimonialization. In answering the question of personal experience in the celebrations closing procession, provided an indicative against possible festival radicalization: I could live the Rocio as another believer and not just as a stranger or a new person. The pilgrimage has integrated me better with my neighbors and friends. In this sense, is that the teacher's view operates as "exaggerated concern" to the universalized weight of the planned school content, and ignoring the explicit recommendations in abundant pedagogic documentation produced and made available. If the cultural heritage, especially in its "immaterial" practices, serves as a starting point (basement) in the reconstruction and mobilization of educational and social skills (Perrenoud, 1999), it left us with a challenge for further discussion: why teachers still fear dealing with "raw material" of its knowledge production? Moreover, when this "material" fully contextualized, why the fear reaches levels of undisguised distancing?

Before this central debate, it is impossible to proceed without dissecting the concept of Geo-education, so we visit the content of students view and the composition of the emerging media of the festival that worked here (see Table 2).

It is also appropriate to note that the days of application and getting the questionnaires were distinct, given for guidance of teachers to best chances to avoid overlapping tasks. It is described, following, the mains aspects resulting from the 12 questions, summarized in the standard model of the questionnaires.

The first question was about what were the shared values (significant attributes) most important in the popular festivities. In this aspect, the students consulted, from the third year, defined as more important the items "traditional", "religious" and "antique”. The other items varied widely in each class. The $3^{\circ}$ year, from Doñana and La

Table 2. Distribution of the interviewed students.

\begin{tabular}{cccccccc}
\hline Institute (IES) & Year & $\mathbf{N}^{\circ}$ of students & Year & $\mathbf{N}^{\circ}$ of students & Year & $\mathbf{N}^{\circ}$ of students & Total \\
\hline LA RIBERA & $3^{\circ}$ & 42 & $4^{\circ}$ & 36 & $5^{\circ}$ & 00 & 78 \\
DOÑANA & $3^{\circ}$ & 13 & $4^{\circ}$ & 38 & $5^{\circ}$ & 20 & 71 \\
& & & Questionnaires & & & 149 \\
\hline
\end{tabular}

Source: Author's elaboration based on field research (2014). 
Ribeira, and the $5^{\circ}$ year (known as bacchillerato) from Doñana, defined the item "economic" as the main aspect of the festivities. In the $4^{\circ}$ year it was marked as more diverse, The item "spectacular" were the second option in Doñana while, in La Ribeira, the item "natural” reached similar amount.

In the next question, when students were asked what would they teach to a foreign — by proximity, the question made reference to a "friend from Madrid"-the students from the three years, highlighted two topics: The National Park of Doñana, for its importance of environmental preservation, and the Church Nossa Senhora da Assunção in the central square of the city, because it was there, at the time, were stayed the Virgin of Rocio.

The following question also requested examples of open suggestions. It asked information on Andalusian festivities, outside Almonte, which were also significant to visit. Although they mentioned other villages in the region, there was a big amount of blank answers or isolated indications pointed without justification. We find nine most mentioned festivities. We observed the predominance of two direct links with the devotion of Rocio: events preceding Pentecost and religious motivations.

When we point out seven examples of typical festivities in Almonte, major part of the answers indicate recognition and meaningful participation in 2 or 3 of them. It is specially mentioned: O Rocio Grande, O Rocio Chico e o Pilgrimage of the Virgin of Rocio. In contrast, there was a significant number of mentions about the lack of another very close religious festival ending the Easter season, and has special presence in Almonte: the Corpus Christi. The next question, solicited a choice, based on the previous question, about which event they liked most, and which aspect value most in their choice. The answers provided gave greater prominence to the Pilgrimage of Virgin of Rocio, followed by Rocio Grande de Pentecostes and Rocio Chico. In one side, it shows the affirmation of the hierarchy of set of Rocio festivities, positioned from the main event in the municipality. Although the last two festivals are annual and the Pilgrimage is an extraordinary event.

About the six question (see Table 3), directed specifically targeted for a more detailed evaluation of the positive and negative aspects of the Pilgrimage of the Virgin. It exposed certain balance between values and concerns about the event. Some ideas are reproduction of what they heard about; other mention denote very direct observation of what was happening in the city in the last months; and expectations of long period in which the Virgin remain in Almonte. To indicate positive and negative aspects of Visit oh the Virgin the respondents indicated:

The next question (see Table 4) aimed to direct alternatives to participate in any event in the Andalusian Community, limiting four types of alternatives: did not participate; yes participate watching TV or through internet; yes participate on vacations; yes has participated every year. Were summarized the answers obtained in the following table.

As can be confirmed under the non-participation (or memory of involvement) in the event is slightly predominant in the set of 149 respondents. This denotes a relative distancing from the students community front of the festive diversity of the region. The need to appoint an event as an example may have collaborated with the proportionally high number of those who did not respond.

The next question centered on the existence of the theme "celebrations" ( in Almonte or Andalusian) in the school curriculum, and it had a significant predominance of the response " didn't study", followed the justification: because it didn't lack. The $3^{\text {rd }}$ Year from the Institute La Ribeira and the $2^{\text {nd }}$ Bacchilerato, were the only

Table 3. Summarizing the answers of the $6^{\text {a }}$ question.

\begin{tabular}{|c|c|}
\hline POSITIVES ASPECTS & NEGATIVE ASPECTS \\
\hline Keep traditions & The path is very long and tiring. \\
\hline The act of Its coming and the possibility of touching it. & There is rudeness in the streets (increase in accidents) \\
\hline The possibility of meeting new people & Too much noise. There are many foreigners (many people) \\
\hline The increase in the economy (tourism) & There is a mismanagement of the economy \\
\hline Religious feelings (Faith, devotion) & There is tumult around the Virgin \\
\hline Family and friendly ties are strengthened & There is few parking lot \\
\hline Emphathy from participants & The traffic becomes congested \\
\hline The event itself and its representation in the region & There are cases that one has to pay to touch the Virgin \\
\hline
\end{tabular}

Source: Author's elaboration based on field research (2014). 
Table 4. Systematization of the answers to the $7^{\text {th }}$ question.

\begin{tabular}{cccccccc}
\hline $\begin{array}{c}\text { Institute and Year } \\
\text { Alternatives }\end{array}$ & $\begin{array}{c}\mathbf{r}^{\text {rd }} \text { Year (13) } \\
\text { Doñana }\end{array}$ & $\begin{array}{c}\mathbf{4}^{\text {th }} \text { Year (38) } \\
\text { Doñana }\end{array}$ & $\begin{array}{c}\mathbf{2}^{\text {nd }} \text { Bach. (20) } \\
\text { Doñana }\end{array}$ & $\begin{array}{c}\mathbf{3}^{\text {rd }} \text { Year (42) } \\
\text { La Ribera }\end{array}$ & $\begin{array}{c}\mathbf{4}^{\text {th }} \text { Year (36) } \\
\text { La Ribera }\end{array}$ & TOTAL \\
\hline Did not participate/do not remember & 03 & 17 & 05 & 26 & 19 & 70 & $47 \%$ \\
Yes, participate through media & 02 & 02 & 00 & 06 & 05 & 15 \\
$\begin{array}{c}\text { Yes, participate on vacations } \\
\text { Yes, has participated every year }\end{array}$ & 00 & 03 & 03 & 01 & 07 & 14 & $43 \%$ \\
\multicolumn{1}{c}{ Didn't answer } & 01 & 07 & 00 & 03 & 02 & 36 \\
\hline
\end{tabular}

Source: Author's elaboration based on field research (2014).

ones with an inverse emphasis on the "yes, I studied". In this case, most of the indications were related to the religion classes (taught in both institutes).

The following question were directed to the pedagogic utility (in terms of students learning) of a school trip in one of this events. The idea was to gather perception of the students about the events in field practice. The "yes", was apparent in almost all the answers, varying only the justifications by grade and schools. In the institute La Ribeira, they said it is possible and we would learn new things about culture. Only 14 answer negatively. In the IES Doñana, the predominance of "yes", from the same reasons, recede a bit, considering that only about $1 / 3$ of the Bacchilerato answer "no".

When asked the main sources about where get information about the Pilgrimage and other Andalusian events, it was very clear, that in both Institutes the interpersonal proximity of these sources. The information comes mainly through the family, neighbors and friends. Then, it still relevant the media such as TV and Internet. Moreover, in third place the direct experience in the events as a participant.

When we refer to the possible impacts that the Pilgrimage brings to Almonte, the answers more emphasizedin a proportion of $90 \%$ of which ones were marked-indicated the positive role of these impacts. In economy, incoming tourism, in recognition of urban values for Rocio culture. What has also showed that the alternative option (denying the impact or its positivity) had more to do with the not understanding the question or unwillingness to answer it.

In the end, the last question sought to explore the future vision of the students about the local potentialities to the future of the event (in this case the next Pilgrimage planned to 2019). The answers highlight what they could offer to the institute (in general) to improve the event to the city and the participants. So the following points were suggested: better security and medical care; better organization oriented to establish rules on the participation of foreigners (referring to a better control on the approach to the ones not devoted to the Virgin); promotion of charity shows and educational activities to young people; taking advantage over the period stay of the Virgin; improvement of street decoration in order to attend the locals and participants; change dates and motivations in order to decrease the frequency of visits; make product prices cheaper.

This tab of the relevant answers from the students didn't have the purpose of showing a contrast with teacher thought, in the school representation in the event context. It has fulfilled, above that, a tracker function of the interface between the recognition of the student community about the limited school relation with the intangible heritage; whether the Pilgrimage or the other cultural events in Andalusia.

\subsection{The Media Projection about the Reference Places in the Pilgrimage}

In complementation to the reading of the representations of the festivity, we highlighted, in summarized plenty way, a short sampling of the form mediatic of projection of the regional visibility of the event. The purpose didn't go to discuss the ideological nature or the direction of these registrations. Just to express that the mediatic registration of the transfer in face of his/her extraordinary characteristic was also reason of the political and socio-environmental discussion. We chose the online journal "Huelva Información" (http://www.huelvainformacion.es/), as a collection platform of the news directly connected to the city of "Almonte"-the word used in the search of the journal database and about the Pilgrimage happenings. The study was a set of 54 news, collected from August 2012 and June 2013.

The first group of news collected concerned about the happenings directly linked to the action of the brother- 
hood Church Main of Almonte, organization responsible for all preparation process, realization and return of the Virgin, during the festivities of the Pilgrimage in the year of the Marian Jubilee. Here we group the 22 news classified as "central"; its contents conveyed the greater devotional practices linked with the traditions between the Rocio Pequeño ("Chico"), in August, and the Rocio Grande, in the Pentecost’s celebration (May/June). The interviews indicated, following, correspond the lines of two important managers of the central devotion; a Jesuit priest José Gonzáles Quevedo, emphasizing the big changes in the Rocio Culture, without weakening the faith intensity. Quevedo was known as the Virgin Poet, receiving the title of "honorary Hermano" from the brotherhood. The other interview shows the lines from the current mayor of Almonte José Antonio Dominguez, of the PP (Popular Party).

Finally, in the Research, we try to understand the importance of chaining scientific research projects in structurally articulated thematic programs. Geo-educational studies have been conducting the range of topics in our laboratory, has not established until now, in a centrifugal condition (centered and radiating) to serve as the axis and expansion of these themes. From there, we feel the necessity to create a macro-project, with effective capacity to explore the Heritage Communication — as a reference subject field of researchers-in the construction of this role. Therefore, approximating Geography and Communication not only tends to include educational and heritage issues, which we question these last seven years, but also guide the external recognition of our studies pattern. The formulation of the following questions can better synthesize this pattern: in the investigated symbolic place, what is the representation communicated by heritage? Each study we developed in LEGE-and from we will disseminate in communication networks - consider the geographical density, (geographicity) the place as mirror/expression of its symbolism. However, the conflictual process of a contemporary Heritage Education - as we indicate in the project, wondering With and Without HE-does not only allows the recognition of symbolism. It requires actions (dialogic and labyrinthine) in the key-heritage choice to decode this place. That should not be accepted in advance as excluding example to the events immaterial heritage. Hence the communication point to the research extension, reminds this is the time to open the continental range (Ibero-American or American-European) of locations, in which we can organize a network of geographic information. Not only to promote the course and to promote the extension of the publications of this work; but also in the strategic duty to produce a set of local information and indicators for planning and management of Heritage Education.

\section{The Festive Rituality in Drawing Geo-Education}

The understanding of this popular event, mediated by "memorial fact" from the religious expression, leads to the recognition of a ritual process. Ritual system (or Rituality) is indispensable to the identification forms and updating of the religious culture in the postmodern reality. It is known that the rites make up the identification of a specific cultural event, and it can translate all a cultural identity of a region, a nation or a civilization.

However, it is the systematic frequency of inherited rites (genetic and historically) that establishes a collective recognition capable to translate in a cultural set of security/comfort. Rituality, thus, positively describes the adaptation on the rite, from the wisdom of a few (priests) to a cooperation of all (participants and devotes). It remains understanding the moment the ritual celebration became a festivity dimension. Moreover, as result, capture, in a phenomenological approach (taken here as inter subjective or relational) three vector forces of contemporary religious space in its capacity to represent itself as geo educative.

To advance the relational approach, what meaning can we associate in the investigation of the religious space in the geo-educational concept? The research presented earlier provides a preliminary indication: geo-education correspond to the exercise of involvement of a community, with its peculiar collective space (symbolic), to effective improvement of evaluative learning. By extension, such improvement requires the equivalent exercise of spatial interpretation of the educational process. Therefore, the geo-education is both a practical and a contextualized knowledge in the ritualization of being on Earth. Accordingly, one can consider the Pilgrimage, the Rocio Celebrations and many other outstanding cultural events of the Andalusia region, a peculiar space, an open symbol to geo-educational improvement. However, for this opening to be promoted from the potential objective plan to relational inter subjective level—as an effective project of heritage appreciation in festive rites-it's indispensable a balanced vector composition (see Figure 3); a relational schema, we try to draw here.

Looking at the picture we see highlighted two triangles $\mathrm{X}$ and $\mathrm{Y}$ positioned in opposite/complementary; as if they were in an ambiguous movement, at the same time approximating and moving away, for a future they fit together. What does permit the installation of this presently "fix"? On one side the vector action of the emerged 


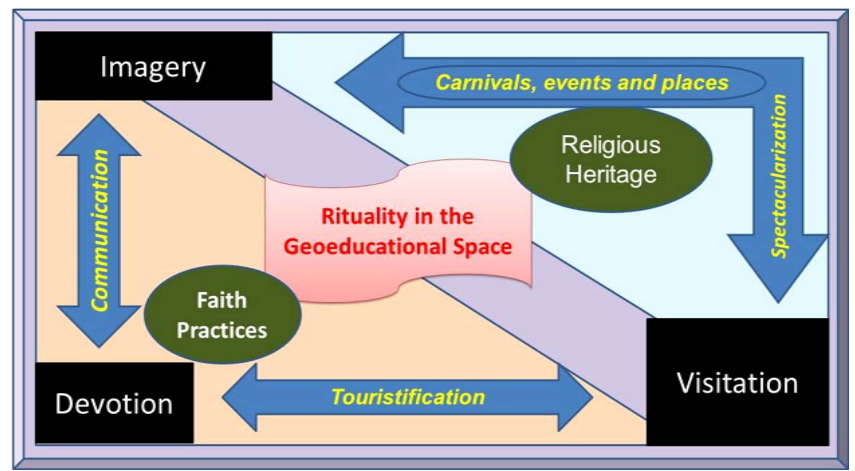

Figure 3. Devotional strategy in Geo-education. Source: Author's elaboration (2014).

symbols of $\mathrm{X}$ reach $\mathrm{Y}$ in the virtual of the Religious Heritage, exposed and opened to political diversity of the geographical access strategies of fixed manifestation (memorials) and fluid (sacred roads). To that, the communicative Imagery and the touristic visitation correspond, in a cooperative way, to the condition of significant sensorial categories; and therefore the geo-educational symbols of radiation than religiosity (communicative and touristic) tends to mark in the contemporary cultural space.

On the other hand, the Virtual Heritage requires more and more engaging paths of experimentation. The religious experience abundant (means shallow, labyrinthine or deep) never showed so many possibilities of living the daily life of groups and individuals, though the experience of radical multiplicity of faith. An effective contract of postmodern rationality in the belief system. In this, both memory and the path to the sacred may involve the direct involve of external participants. Therefore, the symbolic ritual of Carnivalization appoints the modeling of this third symbolic category. That is, the rituality in Geo-education spaces composes a mimesis of the constant civilizing process lead by the Carnival Party. It is a festive model of high capacity, until the twentieth century the coping of emerging fundamentalist issues, mainly in the reading and exclusives values of monotheism. In that way, the Devotional Strategy "closed" itself by the centralism that the carnival rituality tends mark. In the unlimited devotional value space, increasingly rationalized; or in the symbolic event of extraordinary events and endless heritage allegories.

Symbolic categories that we privilege here correspond to structural elements of strong emotional appeal, convergent to multiple meanings. The first one, arising from the religious communication, is polarizing the mystic Imagery. In the case of the Rocio Pilgrimage, automatically recognized for its own figuration of the Virgin, which the mystical peak oh festive rituality is in the traditional pilgrimage of the dawn of Pentecost Mondays.

The second treaty element emerges from progressively converted pilgrim practice in religious tourism. This is the interactive exercise of visitation. In Almonte, the visitation is established at the meeting-fraternal and conflicting-between the brotherhoods (matrix and branches), in the village of El Rocio in the Sacred Paths leading to it or the celebration of the Pilgrimage.

Moreover, the third element, in its contemporary projection, extends the strictly religious ties of practitioners and faithful community to the public and cultural context of devotion. In it, the religious value conforms to a heritage. This is a complex "expansion in scale", generating an apparent and definitive "desecration" of the religious patrimony (church, ritual, images, books or any element of "tradition"). However, this appearance only makes the strength of multiple accesses and interests. A heritage of Catholic or evangelical Christianity, given its intrinsic globality, regardless of the local community recognition; it is surrounded by a massive addition to the dynamics of contemporary, especially after the ecumenical and worldly orientations of the Second Vatican Council. Hence, we understand the community's path of Andalusia from Rocio, as a triangular space whose vertices are Almonte/El Rocio/Brotherhoods; and its projection ( $\mathrm{Y}$ triangle) what the regional geography called the Doñana Park (Natural and National). This rather an environmental heritage of reference to the base scenario of all devotional rites linked to Rocio culture.

Given the triangulation of these categories, we read the devotional strategy (which is nonetheless communication, touristic and carnival as well) as an indispensable draft to the multiple rituality. If the legacy of traditions between generations reached modernity in the current configuration of the educational/school system, in its impact postmodern-it is what we observed in this research-doesn't give up of a contextual and symbolic interde- 
pendence and requires valuating learning. In this sense, a learning that goes beyond the course content (disciplines) in name of the profound sense of symbols (events). This sensewe identified here as the geo-educational complex of the Pilgrimage of the Virgin, in the extraordinary density of the Rocio and Andalusian festivities.

\section{The Vectorial Synthesis of Geo-Education}

The fundamental purpose of this "synthesis" is to permit the convergence of the Religious Heritage analysis (from the Pilgrimage to Marian devotion) as a means to incorporate the debate about two theorems that take into account the cultural foundation of geographical knowledge.

The theoretical dimension that allow us the vector synthesis (or modular) of the categories that we reported above emerges from the seminal work of two contemporary researchers of the complexity of the cultural space. Through the prism of Geography, Professor Paul Claval (2008) pulls together a constellation of religious heritage founding elements in his book Religion et Idélogie: Perspectives géographiques (PUPS, 2008). The author idea runs though the historical debate around the religious world, which has challenged both the classical perspective in scientific Geography and the ability to answer to the geographic implication in the economic, environmental and social fields. However, it is the ideological sphere, linked to the educative formation of values, emerges in all these fields. The book, therefore, faces the ideological modern relationship versus religious spatiality as dimensions in dialogue, growing and fertile. Not only as a "coating content", but a dominant metaphor in so many critics of the illusions of faith. The path, proposed by Claval, structures itself in 10 chapters that starts from the religious investigation through the human sciences. He advances in the religious themes considered more sensible to the human experience, as the habits, regional culture, rituals and myths. Until he rediscover the ideological dilemma, in the second half of twentieth century, gregarious of the ambiguous games of modern and post-modern values. Among his results, the secularization, contrary to what was thought in a ingenuous rationalism, it is possible to include many and diverse belief systems, and the coexistence with the religious symbolism. In this sense, we inferred a fundamental mechanism to form what we present below as Theorem 1. It is an ancestry, that religious and ideological inherit from each other, continue and deep. The Christian recognition to the environment sustainability of faith; and the inclusion of the inalienable right of freedom of belief and mobility cults in secular states, are marking evidence of an updated ancestral legacy.

The second author who sustains us is the researcher in artistic theory, Patrice Pavis (2008), who in 2008 published his book Análise dos Espetáculos: Teatro, Mímica, Dança, Dança-Teatro, Cinema. The book shows the multiplicity and pluralism of approaches to permit the reader, not an expert, the truly semiotic universe that becomes the contemporary scenario. Moreover, here, once we come to another fundamental element to create our second theorem. The scenario, requiring appropriate methods fully adjusted to their objects, exposes itself in triangulations that the work of Pavis shows the following: analysis of conditions, components of the scene and reception conditions. We took special attention to the second stage, to absorb an elementally triangulation vector between space, time and action, which the author will recognize (by inspiration of Mikhail Bakhtin, 1895-1975) as a cronotopos. The interdependence of the three vector elements for the body of the actor/context reconstitute the "setting the scene" formats the cronotopos of the scene.

The cronotopo term is understood in all its relationship with Einstein's relativity theory, which it was introduced to indicate the interdependence between time, space and biology. In literary studies, the cronotopois understood as a "content-formal category" to examine the long process of assimilation of time, space and the real historical individual (Machado, 1990: p. 141).

This is a dialogical representation of time $\Leftrightarrow$ space $\Leftrightarrow$ goods in religiosity, aiming a construction of a contemporary devotional culture. As in Pavis analysis, we can associate the Pilgrimage, not only in its ancestral religiosity (easily understood even by school communities); but also for its dynamic scenario, for its singular "cronotopia". In what way this formulation may contain a generalizing principle, able to point out theorems for a geographical and theatrical phenomenon? To what extent and empirical investigation allows us to make a theoretical systematization, aiming two reasoning of high risk?

We will discuss the theorems recalling the thought of Robert Kaplan, a North American strategist, which is reviving provocations of geographical determinism in the interpretation of conflicting tendencies of the XXI century. His work is centered in the USA (in particular) and the nations committed to institutional democratic order on the decisive role of environmental geography in the continuity of a drawn-world, elementally called 
“map”, which couldn't be disconnected to the geographic scenario. When, in Chapter 3 of his book, The Revenge of Geography (2012), Kaplan calls a group of historians and geographers, treated as "Herodotus successors", and demonstrates the strength of human intrigue (including religious instinct) to reach the geographical boundaries formulating a summary expression that it is worth repeating here: Everything is a matter of geography, until it become a Shakespearean question! (Kaplan, 2012: p. 60) Therefore, the contextual ancestry of the scenario lived in connections of different places; the geo-educational space intensifies its plasticity in multiple vectors. Except in the stagnant compression of the school geography curriculum. We are back, after the vector theorems, in this exciting point.

The geo-education of religious representations, on the "external” ways from the reducing school system, provides a fabric of geographical places in time-space motion of its celebration. For this reason, it can position the human caught (learning) after the direction (teaching). Just like the schools and institutes of an alleged, if not empty "integral education" persistently refuse to do it. That does not prevent its pragmatic and worldly access in a comprehensive, framed in synthesis or representations of school actors. As a rule: a) every place is made of geographicity by a symbolic Pilgrimage of ancestral belonging to other places. Therefore, b) all geographic knowledge legitimizes learning in relational vitality and staged in two or more places. We dedicate ourselves now to a more detailed decoding of each of these formulations.

\section{Formulating Theorems: From Ancestral Geographicity to Theatrical Vitality}

Let us begin by the scathing criticism of Gaston Bachelard to the limitations of basic education (including Geography), compatible with the need for a new scientific spirit of the theorems treatment.

In summary, in elementary school, the remarkable experiences, full of images, are false interests spots. It is essential that the teacher continuously pass from table of experience to the board, in order to extract as soon as possible the abstract from the concrete. When the teacher return to experience, the class will be more prepared to distinguish the organic aspects of the phenomenon. The experiment is designed to illustrate a theorem (Bachelard, 1996: p. 51).

The author of the classic "The Philosophy of No" is here recalled because it helped, very much, the Western thought (fluent, dialogical, and innovative) to avoid stagnation of school illustrated model. Hence the multiple rationalism in the production of new theorems to face the "puerile treasure of our school efforts," in the words of the philosopher. The idea of the theorem affirmation that can be demonstrated do not need teaching accuracies-full of Magic plasticity in the classrooms and empty of fundamentals of science. You need association, dynamic correlations, subtly captained by the experience of geo-educational heritage, rather than its profusion environment. Even though (or precisely because) the school draws a curriculum model of place of knowledge in a community, it is the knowledge from place - therefore its rational reversal-giving substance, form and content, to the meaningful learning. Despite all the contemporary malleability that can be recognized in the conceptions of school curriculum (Valle, 2008; Hernández Cardona, 2002). An open theorem to the formulation of the geoeducacional heritage representations does not require any curriculum design. It emerges simply from the appropriate anthropological and geographical recognition that these places are identified itself by preschool occupation. Nevertheless, from the school communities that identity line can walk into the interior of education systems; or not (as usually happens).

This is the first "demonstrable" theorem of the emissive vector action, considering the communication and tourism variables of its formulation: Every place is made of geographicity by a symbolic transfer of ancestral belonging to other places. It is necessary to warn before the decoding of the theorem, which the category "place”, based on the humanistic approach of Edward Relph (Marandola, Holzer, \& Oliveira, 2012) as a world of involving meanings mobilizes the concept of it in both theorems. Thus, form themselves into geographicity (Dardel, 2011) promotes an imitative need of fluidity that certain items in certain conditions goes in the same direction. The theorem helps us to understand that the whole array of geographic coordinates is religiously accessible by religious symbols. However, every point with contact of two or more power lines, carries with it such a density of meaning that any place, instantly, transformed as the Special place. Be in it, they will be in synchrony with other(s) place(s); as if they accomplished a symbolic transfer through the festive and ritual event. The answer of a student, who participated in the return Pilgrimage of the Virgin to Village, synthetized this perception of grandiosity of the place as ancestral center: Es la Primera time live this experience con conscience, $y$ 
volveré the repetirlacuantasvecespueda" Es la primeravez que vivo estaexperiencia con conciencia, y volveré a repetirlacuantasvecespueda". Moreover, when asked about the benefits...” beneficia a la economía de Almonte (comercio en especial); se conoce más a nuestro Pueblo". Being in Almonte her consciously saw herself in Andalusia, the Spanish geographicity on Earth. However, the first theorem, which expands the religious in the emissive logic, the metaphor of the drop of water falling and dispersing in waves propagation, tends to ignore other emissive events; many of them, which we take as reference, articulates itself as conflicting. This is the spot where the emissive vector becomes articulately receiver of a construction focused on the own land scale. Its formulation even seems to contradict the monographic and focal effect, often used in choosing a continent, country, region, and by extension, one place; as if the human experience mimics an optical zoom.

Different to this zoom linearity, the theorem states has: Every geographic knowledge legitimizes learning in relational vitality and stages two or more places. In this sense the zoom is bifurcated, one, two, three or infinite times. This is because the learning of geo-education-especially given the multiple meanings contained in religious celebrations of this size-is not restricted to sequential or hierarchical methods. The hierarchy, in fact, is expressive and articulate ritual phases and steps of the previous theorem. However, that learning, supported by relational processes, corresponds to random movements able to connect the most diverse places all the time. It is not, therefore, to select certain geographic content, determined in academic formalism. The same that indicates, with perverse and paradoxical tranquility, that the knowledge of the scene and festive scenario does not have pedagogic representation in the teaching geography curriculum. The theorem is formulated by the spatial sense of vitality. Referential quality neglected in conceptualizing what is "geographical" in school. Moreover, it is precisely the theatrical performance, in the significant everyday (harmonic or conflictive) from communities, which revitalizes the human geographic knowledge. This routine is that the extraordinary feeds its usual referenced place as the other place too, where everyone reinvents itself and the vitality is justified on the roads and paths (expected or not).

Here is an example in the speech from two students involved: the first one, when asked what was the think that most marked, said: Vi a unainglesallorarpor que la estavaviendo e entendi que no solo losalmonteños la quieren. The second, highlighting the closing day of the Virgin Pilgrimage, said: El 5 de mayo viviumaexperiênciamuybonita. Por ver a la virgen de reina por las calles de Almonte. El 12 de mayo cumplí uno de mis sueños de meterme a la virgen de pastora. Among the six students from IES La Ribera and the two from IES Doñana, which come back to the complementary part of the questionnaire (pointing out the experience in the event route), we focus on the subtle perception of otherness. An identity maturation process that religious heritage provides in the consolidation of what, in another study (Oliveira, 2012) we conceptualized as Alter-identity. This is, recognizing how much it is necessary to commit the identity value of their culture, in imagistic variations they allow to (I saw Holy as Queen; and saw again a week later, as Shepherdess) or indirectly allow those that approach, although appear in distance (I saw an English cry for what she thought possible to the people of Almonte).

The event place radiates emissive and receptive forms to anchor the representation of religious heritage as geo-education; as in the ancestral geographicity of symbols that attract and reflect devotion, whether in theatrical vitality that random multiplies new learning models. The religious heritage is therefore, simultaneously, as the theorems, an essence (Marandola Jr., 2012) and endless imitations of geographic location.

\section{Conclusion}

The Pilgrimage back to Rocio, concluding the permanence period of the Virgin in Almonte, took place in the second week of May 2013, with all ceremonial expected to the triumphant conclusion of the Jubilee Year. The festival gained a more eloquent relevant involvement with the authorities and believers in a process that would last almost 24 hours [from 10:00 p.m. on Saturday (12 May), to 09:00 p.m. on Sunday (13 May)]. The heat, the dust and the challenges of crossing $15 \mathrm{~km}$ returned this time to wait the preparation of the biggest event of Pentecost weekend was waiting: Rocio Grande and the famous Pilgrimage of Lunes (Monday) in a popular clamor of incomparable public devotion.

The return of the Virgin, therefore, achieves a fully articulated destiny with all the devotional party. It denotes the interdependence of the circuit that involves religion, leisure, tourism, and culture, in one recognition policy for the sacrifice of the noblest causes: making Marian Pilgrimage a celestial theater with two inseparable poles, Almonte and El Rocio. This return a local /regional rituality, which religious and heritage reference justify any 
investment, since it continues under controlof the Brotherhood Matrix de Almonte. The Brotherhood Matrix ismetaphorically the only organization carrying the "Holy Grail": the image of the Pilgrim Virgin.

What is most important to highlight, in the end of this reflection, is the catch-even if cut by empirical absence at the time of the return-of opportunities of teaching experience in the construction of new references of geo educative cooperation. The closure of the Bicentennial Pilgrimage and the Jubilee Year (occurred on 09. 08. 2013) could be interpreted as the end of a cycle. After the extraordinary episode, involving the whole town of Almonte in a continuous ceremonial during nine months, beyond the usual religious, it would be justified a question: About the experience in the Pilgrimage, reported by the geo-educational links, would it strengthen an heritage plan to record the devotional culture of the Virgin of Rocio? We don't highlight this possibility mainly because of the strong policy of heritage valuation that the Autonomous Community of Andalusia and the Kingdom of Spain promote since the democratic consolidation in the 1980s, that prior to the country's entry into the European Union. The broad process of democratic reconstruction and strengthening regional enlists an essential contribution to the cultural forces of regional identity. It is in this way that the perception of a tendency to Patrimonialization of the religious-festive complex of the Rocio (tangible and intangible), it is not discarded.

However, it is in the sphere of social representation, especially for teachers-because the students have a crystalline expression of the hegemonic values from Almonte community-that the central question of this conclusion reaches a more fruitful interest in the understanding of the subsequent process after the Pilgrimage. How do the religious representations of basic education teachers cooperate with the heritage valuation of geo-education, whether in Almonte or anywhere else of devotional irradiation? Considering a "differentiated" pedagogical action, in the clamor of the festivities, it is similar to what we see in the two investigated institutes, and we can conclude that the divorce between school Planning and religious policy of cultural space demarcate an excellent level of relationship by distancing the spheres of formative action. Professionally, the teacher, at the school, does not require any transfer of educational practice to the religious world of the brotherhoods, churches, celebrations or pilgrimages. In this dichotomous way-predominant in this and other studies we have coordinated in Brazil-the geo-education of religious representations implies a heritage education process completely alienated from the school system. The paradox of it is knowing that others institutional systems of civil society, such as commerce, transport, public safety, environmental management, real estate, for example, can interact significantly with the great devotional show in progress. The Rocio Grande encourages, annually, the polarity of Rocio Village as if it becomes a true capital of the Andalusian faith and massively Iberian festivities. While schools of Almonte and from the Village live your days of recess!

However, if the geoeducative reality was less alienated from the school system, promoting curricular and thematic programs correlated with geographicity and vitality from Rocio, both heritages (the school and the religious) would be threatened? Or, could it represent a truly innovative investment in heritage communication in school as the religious culture? Moreover, in this sense, could the teaching religious representations cooperate for the maturation of the knowledge from a place, as the theorems?

The hypothesis stated in the above pages, requires, of course, new research modes. These new methods must be correlated experimentally, but especially in the extension of school and academic practices directly linked to the festivity. The Pilgrimage of the Virgin of Rocio 2012/2013 (see Figure 4) reminds us, happening in the town of Almonte or route to the Village-took place as a major event in its own land use planning, exceeding local/
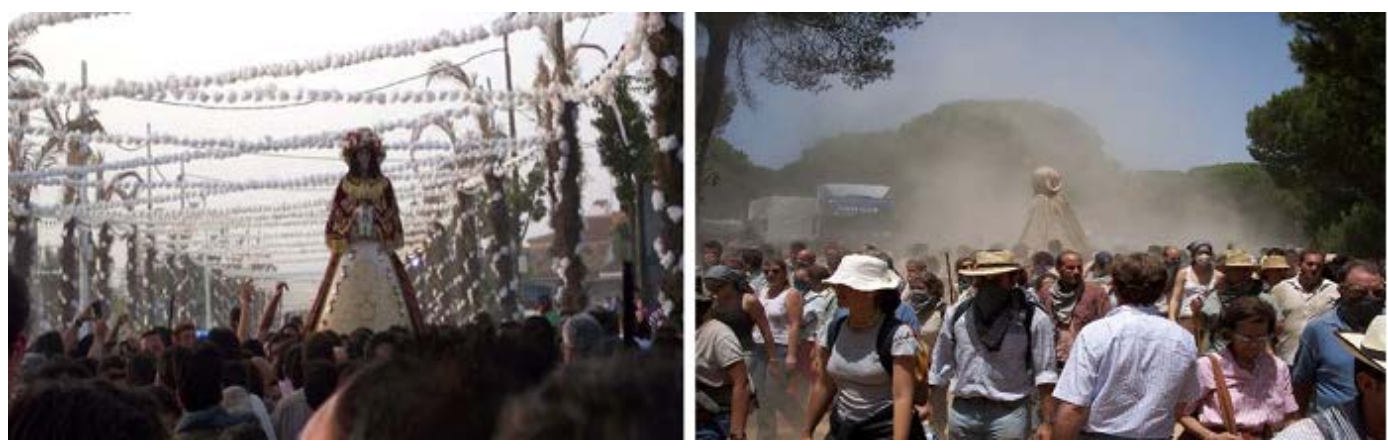

Figure 4. The pilgrimage of the Virgin of Rocio 2012/2013. Source: Author’s personal files Images (2013). 
regional scales, and therefore, operating a Religion Politics Geography as a cultural heritage. Hence, understand it as communicative, tourist and theatrical event associated to a symbolic fluid space. Read, from this research, how such event may move from geo-educational sphere to the curricular level (especially geography) requires significant revision of the teaching academic background. This training needs to receive the heritage dimension as the backbone of the Geography teacher qualification.

\section{References}

Bachelard, G. (1996). A Formação do Espírito Científico. São Paulo: Contraponto.

Bachelard, G. (1968). The Philosophy of No: A Philosophy of the New Scientific Mind. Translated by G.C. Waterston, New York: Orion Press

Cala, J. F. (2005). Historia y documentos de los traslados de la Virgen del Rocío a la Villa de Almonte 1607-2005, Centro de Estudios Rociero, Ayuntamiento de Almonte.

Claval, P (2008). Religion et Idéologie: Perspectives géographiques. Paris: PUPS.

Cuenca López, J. M. (2002). El patrimonio en la didáctica de las ciencias sociales: Análisis de concepciones, dificultades y obstáculos para su integración en la enseñanza obligatoria. PhD Thesis, University of Huelva.

Dardel, E. (2011). O Homem e a Terra: Natureza da Realidade Geográfica. São Paulo: Ed. Perspectiva.

Escalera Reyes, J. (2009). La fiesta como patrimonio (Vol. 21, pp. 53-58). PH, Boletín, Sevilla: IAPH.

Henares Cuéllar, I. L. (2010). La Proteccíon del Patrimonio Histórico en La España Democrática. University of Granada: Granada Editorial.

Hernández Cardona, F. X. (2002). Didáctica de las ciencias sociales, geografía e historia. Barcelona: Graó, D.L.

Instituto del Patrimonio Cultural de España (IPCE), \& Observatorio de Educación Patrimonial en España (OEPE) (2012). Comunicaciones del primero Congreso de Educación Patrimonial. Mirando la Europa: Estado de la cuestión y perspectivas del futuro. http://ipce.mcu.es/portada/destacado37.html

Kaplan, R. (2012). The Revenge of Geography: What the Map Tells Us about Coming Conflicts and the Battle against Fate. New York: Random House.

Machado, I. (1990). A Teoria do romance e a análise estético-cultural de M. Bakhtin (pp. 135-142). Revista Usp, março, abril e maio de 1990. http://www.usp.br/revistausp/05/19-irene.pdf.

Marandola Jr., E. (2013). Fenomenologia e pós-fenomenologia: alternâncias e projeções do fazer geográfico humanista na geografia contemporânea. Geograficidade Journal, 3, 49-64.

http://www.uff.br/posarq/geograficidade/revista/index.php/geograficidade/article/view/123/pdf

Marandola, E., Holzer, W., \& Oliveira, L. de. (2012) Qual o Espaço do Lugar? São Paulo: Ed. Perspectiva.

Martín Cáceres, M. J. (2012) La educación y la comunicación patrimonial: Una mirada desde el Museo de Huelva. PhD Thesis, University of Huelva.

Muñoz Bort, D. (2007). Patrimônio Municipal Público Villa de Almonte: 25 años de democracia municipal Almonte: Ayuntamiento de Almonte, Cuadernos de Almonte 95.

Pavis, P. (2008). A Análise dos Espetáculos: Teatro, Mímica, Dança, Dança-Teatro, Cinema. São Paulo: Editora Perspectiva. Perrenoud, P. (1999). Construir as competências desde a escola. Porto Alegre (RS-Brazil): Artmed Ed.

Oliveira, C. D. M. De (2012). Caminhos da Festa ao Patrimônio Geoeducacional: Como educar sem encenar Geografia. Fortaleza: EdUFC. http://www.repositorio.ufc.br/handle/riufc/10320

Rodriguez Becerra, S. (2006). La Religión de los Andaluces. Málaga: Sarriá.

Sá, C. P. de (1996). Núcleo Central das Representações Sociais. Petrópolis:Vozes.

Valle, I. (2008). O lugar dos saberes escolares na Sociologia Brasileira da Educação. Revista Currículo sem Fronteiras, 8 , 94-108. http://www.curriculosemfronteiras.org/vol8iss1articles/valle.pdf

Vicente Carmona, J. L. de (2010). El fenómeno religioso popular: valores y creencias: Estudio de experiencias religiosas populares en Huelva a principios del siglo XXI. PhD Thesis, Huelva: University of Huelva. 